\title{
Mycosphere Essays 4. Mycorrhizal-associated nutrient dynamics in key ecosystems and their response to a changing environment
}

\author{
Heng $\mathrm{G}^{1,2,3,4}$, Hyde $\mathrm{KD}^{2,3,4}$, Jianchu $\mathrm{X}^{1,2}$, Valentine $\mathrm{AJ}^{5}$ and Mortimer $\mathrm{PE}^{1,2 *}$ \\ 1 World Agroforestry Centre, East and Central Asia, Kunming 650201, China \\ 2 Centre for Mountain Ecosystem Studies, Kunming Institute of Botany, Chinese Academy of Science, Kunming \\ 650201, China \\ 3 Centre of Excellence in Fungal Research, Mae Fah Luang University, Chiang Rai 57100, Thailand \\ 4 School of Science, Mae Fah Luang University, Chiang Rai 57100, Thailand \\ 5 Botany and Zoology Department, University of Stellenbosch, Matieland 7602, South Africa
}

Heng G, Hyde KD, Jianchu X, Valentine AJ, Mortimer PE 2016 - Mycosphere Essays 4. Mycorrhizal-associated nutrient dynamics in key ecosystems and their response to a changing environment. Mycosphere 7(2), 190-203, Doi 10.5943/mycosphere/7/2/8

\begin{abstract}
Environmental change incorporates the full range of natural and anthropogenic changes currently affecting the planet. These changes include fluxes within the carbon and nutrient cycles, resulting in disturbances at the ecosystem level, which may affect plant species distribution as well as soil systems. Mycorrhizal fungi form an important link between plants and soil systems, functioning at the root-soil interface, contributing towards nutrient cycling processes, and, ultimately, influencing the plant composition of terrestrial ecosystems. A more integrated and systemic understanding of these mycorrhizal associations can help us predict, and thus mitigate, the impact of environmental change on biotic communities. In this review we present the latest research on how the carbon, nitrogen and phosphorus dynamics of arbuscular and ectomycorrhiza vary in their representative ecosystems. Furthermore, we also demonstrate how they respond to environmental change, which relates to both biotic and abiotic factors, such as $\mathrm{CO}_{2}$-enrichment, nitrogen-depletion, and the impact of invasive species. This review provides insight on the role of mycorrhiza in offsetting the negative effects of environmental change.
\end{abstract}

Keywords - $\mathrm{CO}_{2}$ enrichment - environmental change - mycorrhiza - nutrient cycling - soil community

\section{Introduction}

The term mycorrhiza refers to the symbiotic relationship between plants and fungi, playing an integral role in the root-soil interface, influencing nutrient cycling and shaping terrestrial ecosystems (Brundrett, 2009). These symbioses link the biosphere with the lithosphere by adjusting nutrient cycling and energy flow.

In the last two decades, research has shown that mycorrhizal fungi are below-ground carbon (C) reservoirs, and their hyphae form an important part of the soil biomass (Högberg \& Högberg 2002, Meyer et al. 2010, Olsson et al. 1999). Moreover, mycorrhizal fungi perform vital roles in degrading, transporting, and acquiring organic nitrogen $(\mathrm{N})$ and phosphorus $(\mathrm{P})$ from the soil through a variety of strategies, and supplying these nutrients to the host plant in exchange for $\mathrm{C}$ (Courty et al. 2010, Fellbaum et al. 2012, Whiteside et al. 2012). Therefore, utilization of 
mycorrhizal fungi in agriculture, horticulture, and forestry has become a potential strategy for sustainable development and reducing the negative effects of environmental change (Verbruggen et al. 2010, Johnson et al. 2013).

Environmental change refers to the full range of natural and anthropogenic changes taking place around our planet, affecting, and often disrupting, all ecosystems. The most prevalent of these changes is climate change, and the associated elevation of atmospheric $\mathrm{CO}_{2}$ (IPCC 2001). However, additional changes such as altered nutrient deposition rates, habitat loss, movement of invasive species, and loss of biodiversity are all key examples of the types of changes associated with a changing environment (Yang et al. 2013). Consequently, as a major functional group of biotic communities, the diversity and distribution of mycorrhizal fungi, has been shown to be greatly affected by environmental change (Dickie et al. 2010, van der Heijden \& Scheublin 2007). Thus, understanding the mechanisms underlying these interactions can help us predict and cope with some of the undesirable impacts caused by the environmental change to the mycorrhizal association (Hu et al. 2013).

Mycorrhizal fungi are widespread in various types of terrestrial ecosystems and consist of several different groups, viz. ectomycorrhiza, arbuscular, ectendomycorrhiza, arbutoid, monotropoid, ericoid, and orchid mycorrhiza (Smith \& Read 2010). Among these mycorrhizal groups the two most dominant and widespread groups are that of arbuscular mycorrhiza and ectomycorrhiza, and have thus received the greatest research focus (Read 1991) (Fig. 1). Arbuscular mycorrhizal fungi is a monophyletic group of fungi within Glomeromycota, which form associations with about $80 \%$ of all land plants, including most agricultural crops (Smith et al. 1997, Bidartondo et al. 2011). Ectomycorrhizal fungi are a diverse phylogenetic group of fungi including Ascomycetes, Basidiomycetes, and Zygomycetes, nearly all of which form symbioses with woody plants (Song et al. 2007). However, these two mycorrhizal groups generally occur in distinct habitats, with arbuscular mycorrhiza being predominantly found in grasslands and rainforests, and ectomycorrhiza predominantly in temperate forests (Read 1991). The difference in the habitats of these mycorrhizas is largely attributed to soil types and N source (Read \& Perez-Moreno 2003).

Numerous excellent reviews related to mycorrhizal nutrient dynamics and their response to environmental change have been published (Read \& Perez-Moreno 2003, Johnson et al. 2013, Phillips et al. 2013). However, the role of these two mycorrhizal groups in nutrient cycling processes and the impact of environmental change on these processes, remain largely undescribed. Thus, we focus on the contribution of ectomycorrhizal fungi and arbuscular mycorrhizal fungi to nutrient cycling processes, and the impact of environmental change on these processes. Furthermore, for the purposes of this review, we focus on temperate forest systems (ectomycorrhiza) and grasslands (arbuscular mycorrhiza) as typical ecosystems for these mycorrhizal groups.

\section{Mycorrhizal associations and nutrient cycling}

Arbuscular mycorrhizal fungi and ectomycorrhizal fungi contribute significantly towards plant nutrient acquisition. $\mathrm{N}$ and $\mathrm{P}$ usually occur in the soil as constituents of organic matter, and the majority of the $\mathrm{N}$ and $\mathrm{P}$ in the soil are unavailable for direct uptake by the roots (MartinezGarcia et al. 2015). Consequently, the mineralization and uptake of these nutrients is driven by a series of decomposition processes, of which ectomycorrhizal fungi and arbuscular mycorrhizal fungi play important roles (Appel \& Mengel, 1998).

Although both mycorrhizal types contribute significantly to host nutrition, there remain distinct differences in their nutrient acquisition strategies. Arbuscular mycorrhizal fungi cannot degrade soil organic matter (SOM) directly (Leigh et al. 2011). They rely on other saprotrophic microorganisms to degrade and release various inorganic nutrients that they can then access (Welc et al. 2010). Whereas, ectomycorrhizal fungi produce hydrolytic and oxidative extracellular enzymes that are capable of degrading SOM, thus facilitating nutrient absorption of their host trees (Courty et al. 2010, Turner 2008).

Despite the different nutrient acquisition strategies of arbuscular and ectomycorrhiza, these symbioses have been shown to improve $\mathrm{C}$ sequestration through increased uptake of $\mathrm{CO}_{2}$ by the 
host plants. In order to provide enough $\mathrm{C}$ to sustain the growth and maintenance of the respective mycorrhizal associations, the photosynthetic rates of the host plants are increased. The mycorrhizal fungus can use more than $20 \%$ of the host plant's photosynthate (Godbold et al. 2006). There is a constant turnover of organic matter, derived from both the host plant and the mycorrhizal fungus, the biomass can store $\mathrm{C}$ in the soil for decades. As a key element of the global $\mathrm{C}$ cycle, forest soils usually function as net $\mathrm{C}$ source, forming the largest reservoir of global soil C (Melillo et al. 1996). Clemmensen et al. (2013) has shown that $70 \%$ of the total soil $\mathrm{C}$ in forests was derived from roots and mycorrhizal fungi, which highlights the importance of mycorrhizal fungi in forest soil $\mathrm{C}$ sequestration. This work is confirmed by that of Prescott (2010) who reported that, the majority of recalcitrant $\mathrm{C}$ in forest soils is derived from fungi and other soil microorganisms.

Numerous experiments have been conducted assessing the nutrient dynamics associated with ectomycorrhizal and arbuscular mycorrhizal fungi, both in the field and under greenhouse conditions (Herman et al. 2012, Leski et al. 2009). Herman et al. (2012) used a microcosm culture unit and an isotopic labelling technique, along with elevated $\mathrm{CO}_{2}$ levels, and reported that plants inoculated with arbuscular mycorrhizal fungi significantly increased the absorption of soil $\mathrm{N}$, under elevated $\mathrm{CO}_{2}$ conditions.

At a landscape scale, the distribution of arbuscular mycorrhizal and ectomycorrhizal plants affect $\mathrm{C}$ cycling patterns, as well as nutrient availability. Phillips et al. (2013) reported that when surveying the abundance of arbuscular mycorrhizal and ectomycorrhizal trees in the eastern and mid-western United States, their analysis suggested that mature forests with these two kinds of trees showed a remarkably even distribution pattern. However, the results also indicated that these two systems had distinctly different nutrient economies. In arbuscular mycorrhizal dominated systems, the associated leaf litter and root exudates were driving a rapid $\mathrm{C}$ and $\mathrm{N}$ mineralization process from organic to inorganic (Finzi et al. 1998, Drigo et al. 2010). Within this system, inorganic $\mathrm{N}$ and $\mathrm{P}$ are the common forms. The arbuscular mycorrhizal fungi absorb and transport these inorganic nutrients to their host plant, in a process known as arbuscular mycorrhizal fungal nutrient economy or inorganic economy (Phillips et al. 2013). Contrastingly, in ectomycorrhizal forest systems, the ectomycorrhizal nutrient economy, or the organic economy, which is characterised by the limited release of inorganic nutrients into the soil due to low-quality litter and slow $\mathrm{C}$ turnover, is predominant (Phillips et al. 2013). This organic nutrient economy is characterized by slow litter decomposition rates, resulting in accumulation of recalcitrant $\mathrm{C}$ and SOM. This pool of SOM remains unavailable to many non-ectomycorrhizal fungal plants, but can be utilized by ectomycorrhizal fungi, thus providing a steady supply of additional $\mathrm{N}$ and $\mathrm{P}$ to the host plants (Read \& Perez-Moreno, 2003).

The paper by Read \& Perez-Moreno (2003) highlights the main ecosystems dominated by arbuscular mycorrhiza (grasslands) and ectomycorrhiza (temperate forests). Based on the review by Read \& Perez-Moreno (2003) we have focused on grassland and temperate forest ecosystems for our discussion of how environmental change will impact on the nutrient dynamics of arbuscular and ectomycorrhizal fungi (Fig. 2).

\section{Role of ectomycorrhizal fungi in temperate forest ecosystems}

Temperate forests are characterized by mild climates, with slow decomposition of soil organic matter, and poor $\mathrm{N}$ supply (Taylor 1983). The soils within these forests usually consist of an accumulation of organic matter on top of the mineral soil, and a distinct vertical stratification, with the age of soil organic matter increasing with depth (Trumbore \& Harden 1997). The tree species in temperate forests are predominantly ectomycorrhizal, resulting an ectomycorrhizal fungal dominance of the soil fungal communities within these forests (Read 1991, Shi et al. 2014). The majority of ectomycorrhizal fungi are also saprophytic, thus providing a diverse set of ecological roles for these fungi (Hibbett et al. 2000). For example, in high-latitude ecosystems where plant productivity most limited by low soil $\mathrm{N}$ availability, ectomycorrhizal mediated $\mathrm{N}$ acquisition strategies are employed by the majority of the local plants (Mayor et al. 2015). 
The two major forms of $\mathrm{C}$ in forest soil systems are plant organic $\mathrm{C}$ (plant litter and woody material) and SOM (Lonsdale 1988). Ectomycorrhizal fungi are able to degrade both of these C substrates, breaking down plant organic C, which is then later released into the soil system as SOM, as well as the metabolizing SOM (Talbot et al. 2008). Ectomycorrhizal fungi are able to produce several extracellular enzymes that are involved in $\mathrm{C}$ cycling. Sucrose is the most common form of $\mathrm{C}$ for transport and is easily hydrolysed to a monosaccharide, which is a form of $\mathrm{C}$ that is available to other soil organisms and plants (Nehls et al. 2001). Ectomycorrhizal fungi also obtain substantial amounts of $\mathrm{C}$ from their host plant, thus driving up $\mathrm{C}$ capture through increased photosynthetic rates (Read \& Perez-Moreno 2003). It has been reported that $\mathrm{C}$ can flow bidirectionally between two plants, through the mycorrhizal mycelium network, thus assisting in $\mathrm{C}$ cycling processes (Finlay \& Read, 1986, Simard et al. 1997).

An additional reserve of $\mathrm{C}$ in temperate forest soils is from ectomycorrhizal fungal mycelium. Hogberg \& Hogberg (2002) found that in a coniferous forest, one third of the soil biomass was derived from ectomycorrhizal fungi. Furthermore, ectomycorrhizal fungal mycelium has a rapid growth rate and produces a high number of C-rich fruiting bodies (Leake et al. 2004), all of which are reliant on the host plant for photosynthetically derived C. Soil organic matter, including dead ectomycorrhizal fungal sporocarps and mycelia, provides an alternative source of $\mathrm{C}$ for ectomycorrhizal fungi and their associated trees, especially when photosynthetic $\mathrm{C}$ is low or unavailable. This phenomenon most commonly occurs in winter, when sunlight is limited (Buee et al. 2007), and in declining forests (Mosca et al. 2007).

Carbon allocation from plant to mycorrhizal fungi is influenced by nutrient availability (Treseder 2008). Treseder (2004) found low mycorrhizal colonization in agricultural fields enriched with N. Ectomycorrhizal fungi decompose and utilize SOM using extracellular enzymes such as proteases and polyphenol oxidase (Griffiths \& Robinson, 1992). Hobbie (2006) determined 43\% of the total $\mathrm{C}$ in a mycorrhizal fruiting body was obtained from the soil $\mathrm{C}$ pool.

Ectomycorrhizal fungi are also involved in the mobilization, transport and dissolution of minerals and nutrients, such as $\mathrm{N}$ and $\mathrm{P}$ (Philips et al. 2013, Talbot et al. 2008). In temperate forests, $\mathrm{N}$ and $\mathrm{P}$ are primarily stored in complex organic forms, which are unavailable to plants, thus the plants are reliant on ectomycorrhiza for access to these nutrients (Lilleskov et al. 2011). Ectomycorrhizal fungi form a reliable source of $\mathrm{N}$ and $\mathrm{P}$, mostly in the form of amino acids, proteins, lingo-cellulose, and polyphenol protein complexes (Allen et al. 2003, Leake et al. 2004). Zeglin et al. (2013) found that in an old-growth Douglas-fir forest, amino-sugars, derived from microbial cell walls, formed an important source of $\mathrm{C}$ and $\mathrm{N}$ for ectomycorrhizal fungi. Avolio et al. (2012) also found that ectomycorrhizal fungi have several ammonium transporter genes, which are involved in the utilization and assimilation of $\mathrm{N}$, and these genes are regulated by different $\mathrm{N}$ sources.

Ectomycorrhizal fungi enhance $\mathrm{P}$ and $\mathrm{C}$ content in soil by releasing organic molecules such as chelating compounds and hydrogen ions, and subsequently affect soil pH (Taylor et al. 2009). Potila et al. (2009) investigated the biomass of ectomycorrhizal fungi under varying concentrations of $\mathrm{P}$ and $\mathrm{K}$ in a peat land forest, and found that ectomycorrhizal biomass was increased by $\mathrm{P}$ deficiency. Furthermore, Bougher et al. (1990) reported that all ectomycorrhizal fungi studied in their research, including Pisolithus tinctorius, Descolea maculate, and Laccaria laccata, increased the plant P content under low P availability. Similarly, Jones et al. (1998) reported that the P inflow rates of Eucalyptus trees colonized by ectomycorrhizal fungi were 3.8 times higher in comparison to those of non-mycorrhizal trees. Alternatively, high inorganic P availability has been shown to decrease ectomycorrhizal fungal growth rates (Ekblad et al. 1995). Beside degradation of SOM and transport of $\mathrm{N}$ and $\mathrm{P}$, ectomycorrhizal fungi help their host plants to utilize other nutrients, such as $\mathrm{Ca}^{2+}$ (Blum et al. 2002), $\mathrm{K}^{+}$(Van Scholl et al. 2006), $\mathrm{Mg}^{2+}$ (Leyval \& Berthelin 1989), and $\mathrm{Fe}^{3+}$ (Machuca et al. 2007).

Ectomycorrhizal fungi, however, do not function in isolation in soil. Many bacterial communities are also associated with these fungi (Uroz et al. 2007). These bacteria, known as 
ectomycorrhizosphere bacteria, or mycorrhizal helper bacteria, the majority of these bacteria belong to the genera Burkholderia and Collimona (Barbieri et al. 2007). These bacteria are able to promote ectomycorrhizal fungal hyphal growth, increase the absorptive surface of hyphae, and weather complex minerals and soil particles (Calvaruso et al. 2006; Wu et al. 2008).

\section{Nutrient dynamics of arbuscular mycorrhizal fungi in grassland ecosystems}

Grasslands are distributed throughout most climatic zones and comprise about twenty percent of terrestrial ecosystems (Sun et al. 2013). Compared to temperate forests, the soils in grassland ecosystems are highly acidic and generally have limited content of $\mathrm{P}$ and $\mathrm{N}$ (Helgason et al. 1998). Arbuscular mycorrhizal fungi are the dominant mycota in grassland ecosystems (Read \& Perez-Moreno 2003).

The most notable function of arbuscular mycorrhizal symbioses in grassland ecosystems is the uptake and supply of P and N to the host plant, by the mycorrhizal fungus (Smith \& Read 2010). The hyphae of arbuscular mycorrhizal fungi extend into the soil matrix beyond the rhizosphere, thereby vastly increasing the area of soil that can be mined for nutrients in comparison to the host's root system (Bolan 1991). An additional, indirect mechanism by which arbuscular mycorrhizal fungi assist the host plant in acquiring P has been shown by Nazeri et al. (2014). These authors reported that arbuscular mycorrhizal fungi are capable of affecting both the carboxylate concentrations and the $\mathrm{pH}$ of the rhizosphere of five legumes (Kennedia prostrata, Cullen australasicum, Bituminaria bituminosa, Medicago sativa and Trifolium subterraneum), thereby impacting the $\mathrm{P}$ availability within the rhizosphere. In addition to $\mathrm{P}$ acquisition, arbuscular mycorrhizal fungi also assist their host plant in assimilating inorganic $\mathrm{N}$, e.g. $\mathrm{NH}^{4+}$ and $\mathrm{NO}^{3-}$ (Fig. 3). As with P, the hyphal network of the arbuscular mycorrhizal fungi further provide access to soil $\mathrm{N}$ in areas beyond the rhizosphere (Bago et al. 1996). After the inorganic $\mathrm{N}$ is taken up by the mycorrhizal hyphae, it is converted into arginine, which is the primary form in which $\mathrm{N}$ is transported through the hyphal network (Tian et al. 2010). The arginine molecules are transported from the extraradical hyphae to the intraradical hyphae where they are broken down, releasing the $\mathrm{N}$ which is then available for plant assimilation (Tian et al. 2010).

In an indirect mechanism of $\mathrm{N}$ assimilation, arbuscular mycorrhizal fungi influence $\mathrm{N}$ cycle in soil within the litter decomposition process, by interacting with the soil decomposer community. Herman et al. (2012) used air-gap microcosms to investigate the effect of arbuscular mycorrhizal fungi on the microbial mediation of litter decomposition of Plantago lanceolata, showing that the decomposer community succession was influenced by the presence of arbuscular mycorrhizal fungi, leading to an enhanced uptake of plant $\mathrm{N}$.

Although arbuscular mycorrhizal fungi are generally not considered to be saprotrophic organisms, there have been reports that these fungi can be directly involved in both accelerating grass litter decomposition processes, and also acquiring $\mathrm{N}$ directly from organic materials, which indicates that, at least in a limited amount of circumstances, arbuscular mycorrhiza can have saprotrophic capabilities (Hodge 2001, Hodge et al. 2001). Govindarajulu et al. (2005) and Tian et al. (2010) have shown that arbuscular mycorrhizal fungal hyphae can rapidly colonize soil patches, as well as acquire and transport both inorganic (Jin et al. 2005) and organic N, such as amino acids, from the soil (Whiteside et al. 2012). Furthermore, numerous studies have reported that SOM associated with plant roots colonized by arbuscular mycorrhizal fungi is decomposed at a faster rate than the SOM associated with uncolonised root systems (Bird et al. 2011, Hodge et al. 2001, Paterson et al. 1999).

\section{The impact of environmental change on mycorrhizal dynamics}

The effects of environmental change (rising atmospheric $\mathrm{CO}_{2}$ levels, increased $\mathrm{N}$ deposition rates, altered precipitation, and a warming climate) impact all ecosystems (De Souza et al. 2015) and thus, mycorrhizal communities will be influenced through this process (Johnson et al. 2013). Elevated $\mathrm{CO}_{2}$ levels and increased rates of $\mathrm{N}_{2}$ deposition are the two major factors influencing plant 


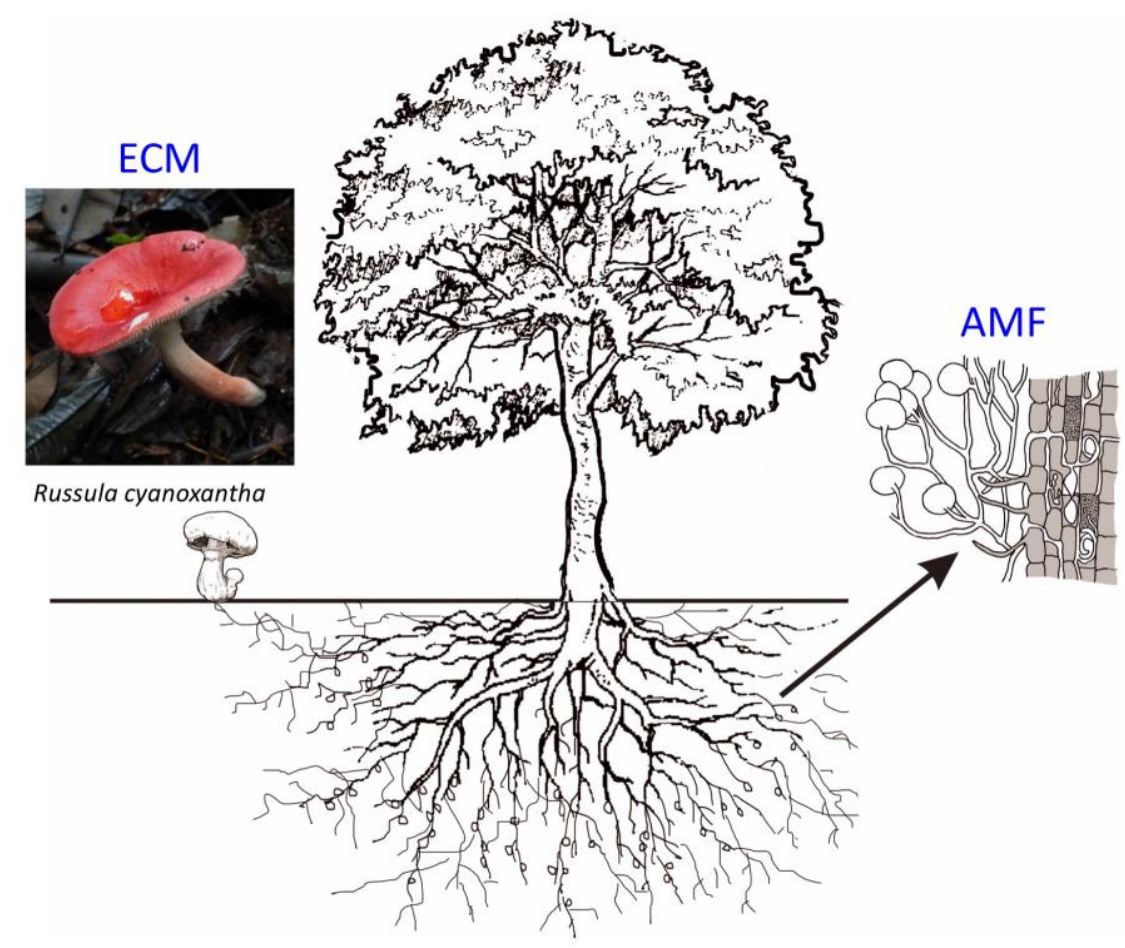

Fig. 1 - Diagram depicting both ectomycorrhizal fungi (ECM) and arbuscular mycorrhizal fungi (AMF). Russula cyanoxantha is an example of a fruiting body of ectomycorrhizal fungi. The insert shows arbuscular mycorrhizal arbuscules within the root cortical cells.

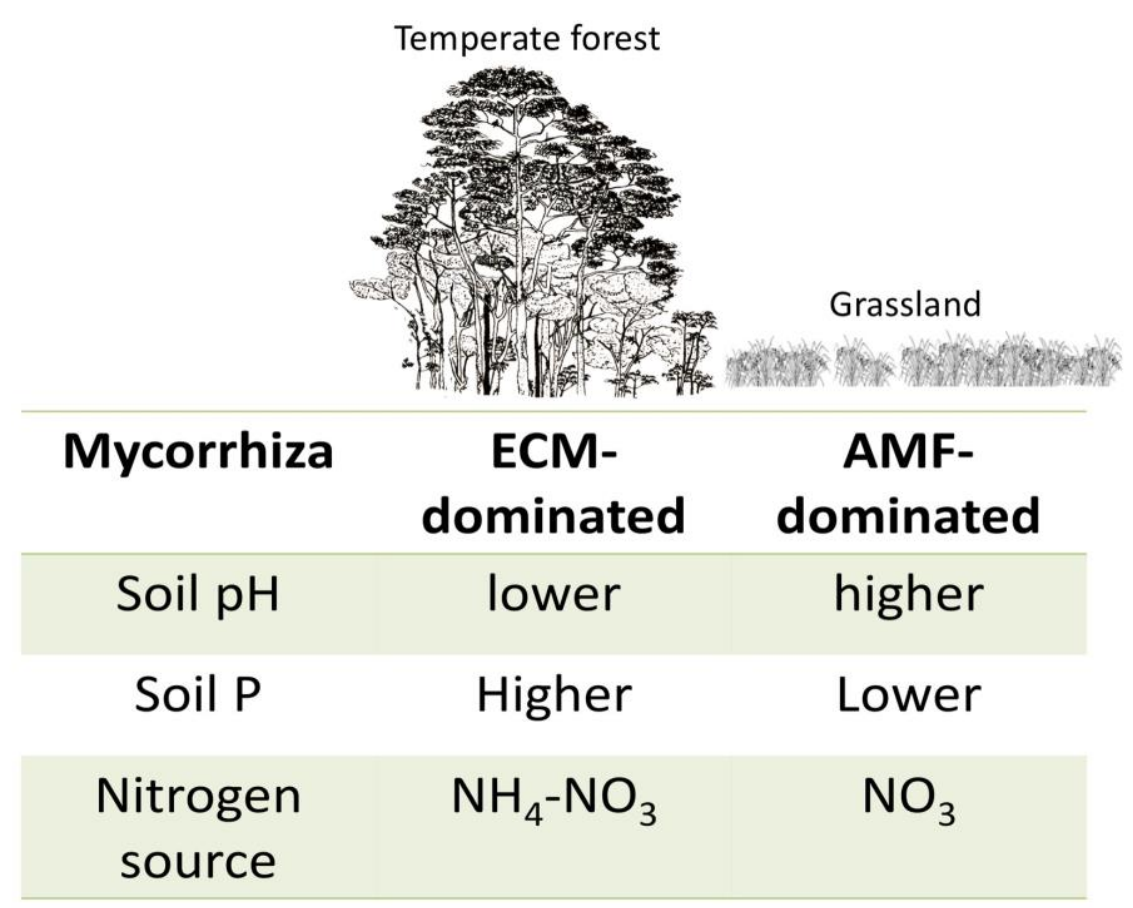

Fig. 2 - Generalized soil conditions characteristic of arbuscular mycorrhizal fungi (AMF) and ectomycorrhizal fungi (ECM). The main ecosystems for the respective mycorrhizal types are shown here as temperate forest systems for ectomycorrhizal fungi and grasslands and tropical forests for arbuscular mycorrhizal fungi. 
communities and the associated mycorrhizal fungi, and will thus form the two main points in our review of the impacts of environmental change on mycorrhizal dynamics (Clark \& Tilman 2008, Drigo et al. 2008, Rillig et al. 2007). The impact of environmental change can be characterized as either direct (e.g. plant and mycorrhizal growth change, plant and mycorrhizal community shift) or indirect (e.g. C sequestration, plant-soil feedback), and long term or short term (Fig. 4).

\section{Effects of elevated $\mathrm{CO}_{2}$}

Over the last century, human activity, such as fossil fuel combustion and deforestation, has significantly increased the $\mathrm{CO}_{2}$ concentration in the atmosphere by $c a .1 .8 \mu \mathrm{mol} . \mathrm{mol}^{-}{ }^{-}$.year ${ }^{-1}$ from $280 \mu \mathrm{mol} . \mathrm{mol}^{-1}$ before the industrial revolution and projected to reach $700 \mu \mathrm{mol} . \mathrm{mol}^{-1}$ by the end of this century (Srinivasarao et al. 2016). Elevated $\mathrm{CO}_{2}$ levels are both a cause for concern due to the effect on raising atmospheric temperatures, but they also can have a positive impact on plant and mycorrhizal growth, a process known as $\mathrm{C}$ fertilization (McGrath and Lobell. 2013). Past studies have shown that elevated atmospheric $\mathrm{CO}_{2}$ concentrations increase the biomass of roots and mycorrhizas (Drigo et al. 2008), thus increasing the terrestrial C pool. Antoninka et al. (2011) found that, after seven years of treatment, $\mathrm{CO}_{2}$ enrichment $(560 \mathrm{ppm})$ increased the hyphal length and spore size of arbuscular mycorrhizal fungi. In a meta-analysis, based on published data from field studies in which mycorrhizal abundance was measured in response to long-term (>2 months), large-scale $\left(>1 \mathrm{~m}^{2}\right.$ ) manipulations of $\mathrm{CO}_{2}$ availability, it was also found that $\mathrm{CO}_{2}$ enrichment consistently and positively increased both arbuscular mycorrhizal and ectomycorrhizal fungal growth, by an average of $47 \%$, across all studies (Treseder 2004). Based on this evidence, these authors concluded that these mycorrhizal fungi have a similar response to $\mathrm{CO}_{2}$ enrichment.

Increases in atmospheric $\mathrm{CO}_{2}$ levels have also been shown to accelerate litter decomposition, thus releasing soil $\mathrm{C}$ at a faster rate. Philips et al. (2012) revealed that, after treating a pine forest with elevated $\mathrm{CO}_{2}$ for 14 years, $\mathrm{CO}_{2}$ enrichment enhanced litter decomposition rates due to a more rapid turnover of roots and ectomycorrhizal fungal structures. These results indicate that mycorrhizas speed up the decomposition of soil organic matter; which has been confirmed by several other studies (Cheng et al. 2012, Herman et al. 2012, Hodge et al. 2001, Iversen et al. 2012). Cheng et al. (2012) observed that, in the presence of arbuscular mycorrhizal fungi, fresh aboveground plant litter decomposed faster than the non-arbuscular mycorrhizal fungi controls under elevated $\mathrm{CO}_{2}$ levels. These findings suggest that, when exposed to elevated levels of $\mathrm{CO}_{2}$, arbuscular mycorrhizal fungi can accelerate litter decomposition rates, resulting in a decline in soil $\mathrm{C}$ pools. Furthermore, elevated $\mathrm{CO}_{2}$ can induce a $\mathrm{N}$ limitation due to a lowering of the $\mathrm{C} / \mathrm{N}$ ratio in the soil. Under $\mathrm{N}$ limiting and elevated $\mathrm{CO}_{2}$ conditions, arbuscular mycorrhizal fungi produce higher concentrations of glomalin in order to stimulate free-living soil fungi to acquire recalcitrant forms of organic N (Clemmensen et al. 2015, Welc et al. 2010).

\section{Effects of $\mathrm{N}$ deposition}

In addition to $\mathrm{CO}_{2}$ enrichment, increasing inputs of $\mathrm{N}$ derived from anthropogenic sources, such as $\mathrm{NO}_{2}$ and $\mathrm{NO}_{3}$, are released by fuel combustion and $\mathrm{N}$ fertilization of agricultural landscapes, are entering into the biosphere (Vitousek et al. 1997). The primary effects of $\mathrm{N}$ deposition on natural ecosystems are seen in the changes in the soil nutrient profiles and soil chemistry, which have direct impacts on the plant and mycorrhizal communities associated with these soils. One example of these changes is presented by the work of Liu et al. (2012), who reported a decline in mycorrhizal diversity as a result of high $\mathrm{N}$ deposition rates.

There have been contradictory reports regarding the responses of arbuscular mycorrhizal and ectomycorrhizal fungi to $\mathrm{N}$ enrichment (e.g. Holden \& Treseder 2013, Ochoa-Huseso et al. 2013). In order to analyse the affects of $\mathrm{N}$ enrichment on different ectomycorrhizal forests, Magill et al. (2004) conducted an experiment incorporating a series of $\mathrm{N}$ fertilization treatments using two contrasting temperate forest types (a red pine plantation and a mixed hardwood stand) as treatments. Further evidence for the effects of $\mathrm{N}$ enrichment of mycorrhizal systems is provided by 


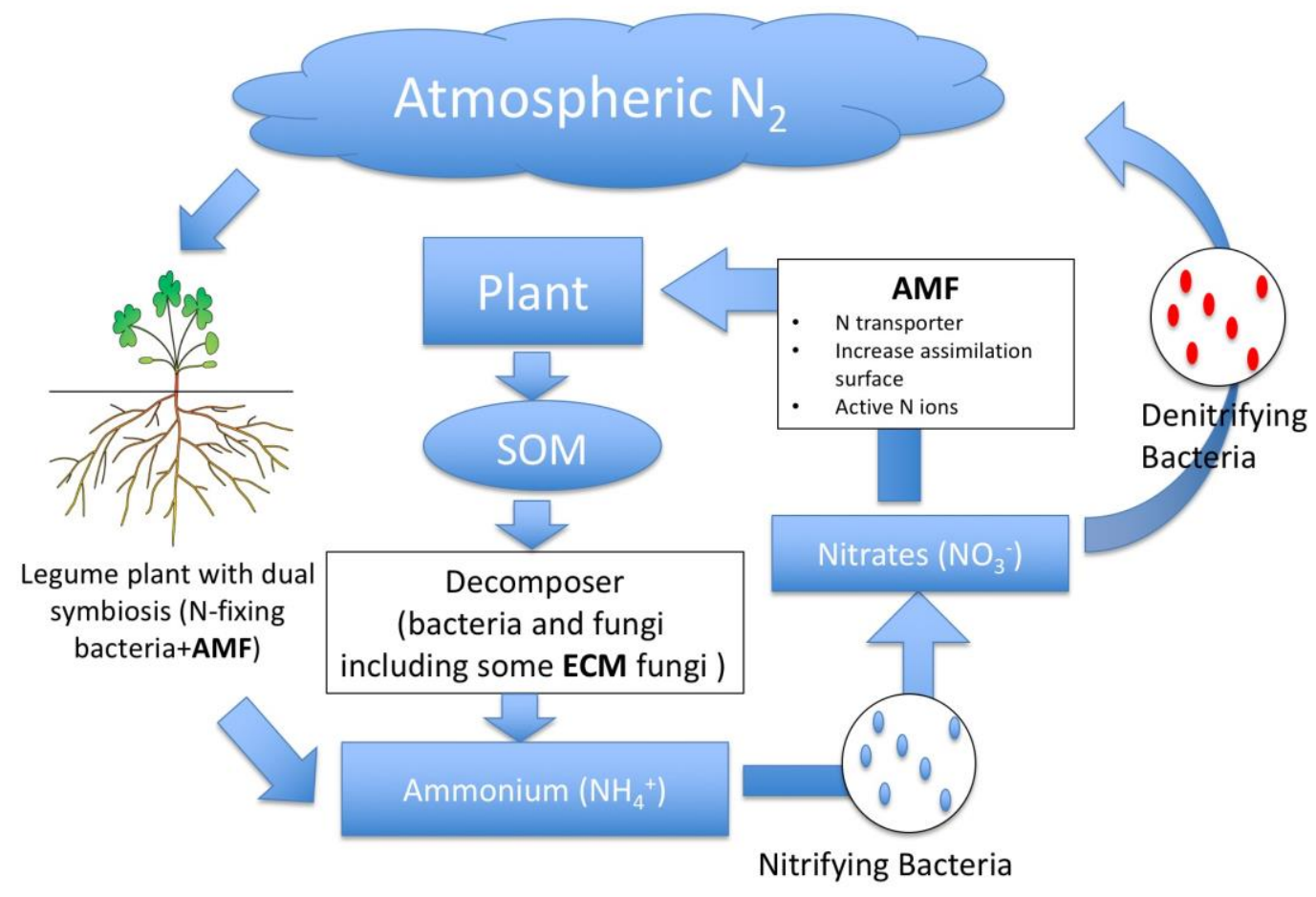

Fig. 3 - The role of arbuscular mycorrhizal fungi (AMF) and ectomycorrhizal fungi (ECM) in the nitrogen cycle. AMF mainly are involved in assisting $\mathrm{N}$ transportation and assimilation while ECM can act as the direct decomposer of the organic $\mathrm{N}$ source.

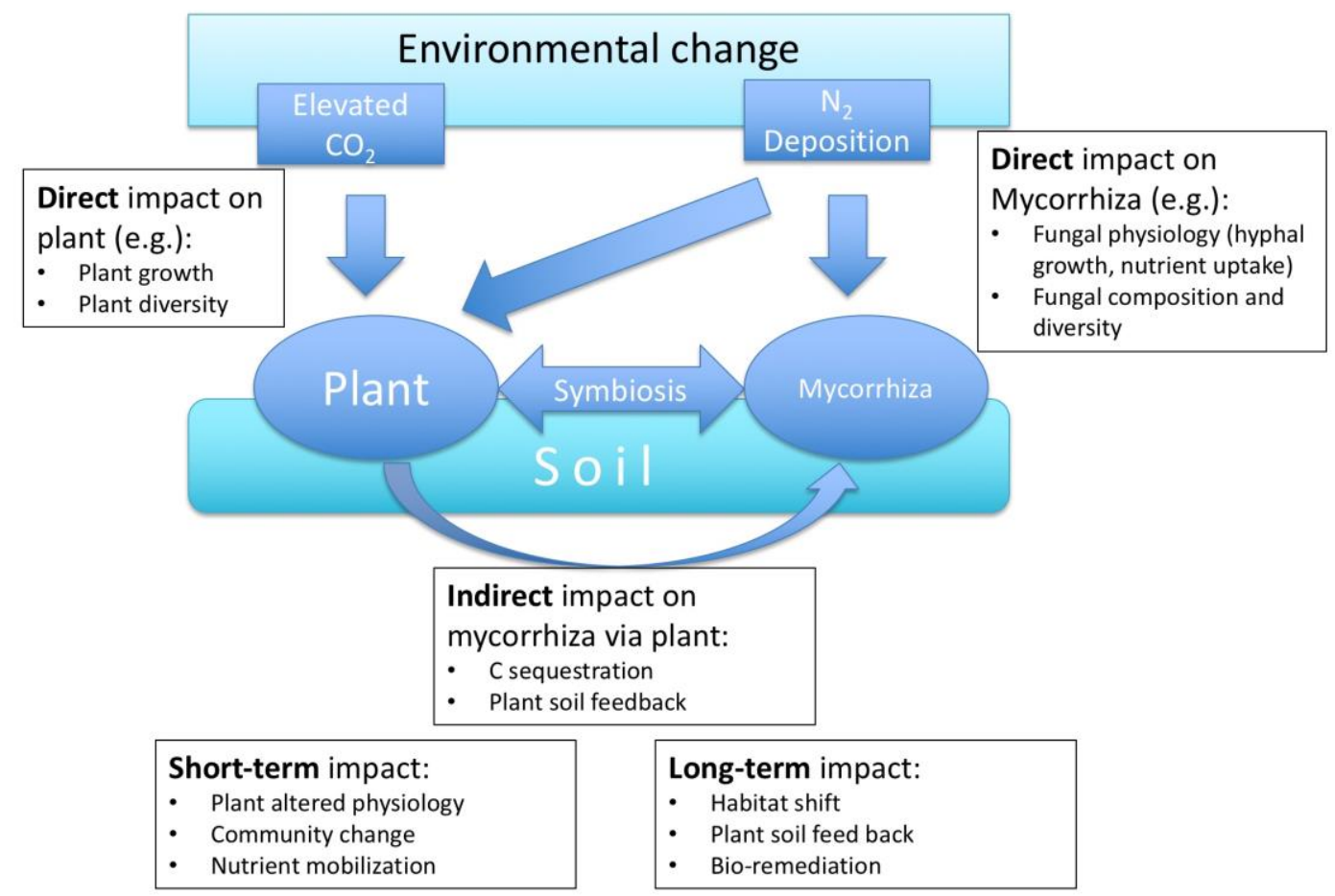

Fig. 4 - The influence of environmental change on host plants and associated mycorrhizal partners. Environmental change has both a direct and an indirect impact on the plant or mycorrhizal communities. In response, plant and mycorrhizal communities are able to alter their physiology or habitat to remediate the long- or short-term impacts of environmental change. 
Ochoa-Hueso et al. (2013). These authors tested the responses of plants and their associated mycorrhizal fungi to $\mathrm{N}$ fertilization by adding $\mathrm{NH}_{4}{ }^{+}$and $\mathrm{NO}_{3}{ }^{-}$to the systems for period of 1.5 years, at four different application rates $\left(0,10,20\right.$, and $\left.50 \mathrm{~kg} \mathrm{~N} \cdot \mathrm{ha}^{-1} \cdot \mathrm{y}^{-1}\right)$. This study showed that some of the experimental plants and their associated ectomycorrhiza were negatively affected by $\mathrm{N}$ fertilization, in terms of density and growth. $\mathrm{N}$ enrichment experiments conducted in arbuscular mycorrhizal forests have shown that the trees in these forest systems have positive biomass responses to the additional $\mathrm{N}$ applied, highlighting the different responses of arbuscular mycorrhizal and ectomycorrhizal fungal plants to N enrichment (Boggs et al. 2005, Pregitzer et al. 2008). Thomas et al. (2010) used forest inventory data to examine the impact of $\mathrm{N}$ deposition on tree growth, survival, and $\mathrm{C}$ storage, across a variety of forest types. These authors reported that $\mathrm{N}$ deposition enhanced aboveground biomass of all tree species with arbuscular mycorrhizal fungi associations, whereas the biomass of ectomycorrhizal fungi dominated forests could either decrease or increase in response to $\mathrm{N}$ enrichment.

\section{Conclusion}

Mycorrhizal fungal communities play a number of important roles in numerous ecological processes in terrestrial ecosystems, including $\mathrm{C}$ sequestration, nutrient cycling, and the facilitation of growth and nutrient absorption for host plants. However, mycorrhizal fungi have been shown to be susceptible to environmental change, although the exact response varies according to mycorrhizal type, ecosystem type, and the nature of the change.

The sequestration of $\mathrm{C}$ and the uptake and metabolism of various forms of $\mathrm{N}$ are particular mycorrhizal benefits in the adaptation to environmental change. These mycorrhizal benefits underpin the distribution of native plants and can help ensure the long-term survival of their host species when exposed to environmental change.

In order to fully understand how environmental change impacts terrestrial ecosystems and, more specifically, mycorrhizal systems, an integrated approach is required in our research efforts. We need to investigate the potential responses of mycorrhizal distribution patterns, and plant-soilmycorrhizal interactions to changing environmental conditions. Therefore, now more than ever, there is a critical need for collaborative and constructive work across disciplines, and for closer collaboration between the modern technologies and the more traditional disciplines of taxonomy, anatomy, and physiology.

\section{References}

Allen MF, Swenson W, Querejeta JI, Egerton-Warburton LM, Treseder KK. 2003 - Ecology of mycorrhizae: A conceptual framework for complex interactions among plants and fungi. Annual Review of Phytopathology 41, 271-303.

Antoninka A, Reich PB, Johnson NC. 2011 - Seven years of carbon dioxide enrichment, nitrogen fertilization and plant diversity influence arbuscular mycorrhizal fungi in a grassland ecosystem. New Phytologist 192, 200-214.

Appel T, Mengel K. 1998 - Prediction of mineralizable nitrogen in soils on the basis of an analysis of extractable organic N. Zeitschrift Fur Pflanzenernahrung Und Bodenkunde 161, 433452.

Avolio M, Muller T, Mpangara A, Fitz M, Becker B, Pauck A, Kirsch A, Wipf D. 2012 Regulation of genes involved in nitrogen utilization on different $\mathrm{C} / \mathrm{N}$ ratios and nitrogen sources in the model ectomycorrhizal fungus Hebeloma cylindrosporum. Mycorrhiza 22, $515-524$.

Bago B, Vierheilig H, Piche Y, AzconAguilar C. 1996 - Nitrate depletion and pH changes induced by the extraradical mycelium of the arbuscular mycorrhizal fungus Glomus intraradices grown in monoxenic culture. New Phytologist 133, 273-280. 
Barbieri E, Guidi C, Bertaux J, Frey-Klett P, Garbaye J, Ceccaroli P, Saltarelli R, Zambonelli A, Stocchi V. 2007 - Occurrence and diversity of bacterial communities in Tuber magnatum during truffle maturation. Environmental Microbiology 9, 2234-2246.

Bidartondo MI, Read DJ, Trappe JM, Merckx V, Ligrone R, Duckett JG. 2011 - The dawn of symbiosis between plants and fungi. Biology Letters 7, 574-577.

Bird JA, Herman DJ, Firestone MK. 2011 - Rhizosphere priming of soil organic matter by bacterial groups in a grassland soil. Soil Biology \& Biochemistry 43, 718-725.

Blum JD, Klaue A, Nezat CA, Driscoll CT, Johnson CE, Siccama TG, Eagar C, Fahey TJ, Likens GE. 2002 - Mycorrhizal weathering of apatite as an important calcium source in base-poor forest ecosystems. Nature 417, 729-731.

Boggs JL, McNulty SG, Gavazzi MJ, Myers JM. 2005 - Tree growth, foliar chemistry, and nitrogen cycling across a nitrogen deposition gradient in southern Appalachian deciduous forests. Canadian Journal of Forest Research-Revue Canadienne De Recherche Forestiere 35, 1901-1913.

Bolan NS. 1991 - A critical review on the role of mycorrhizal fungi in the uptake of phosphorus by plants. Plant and Soil 134, 189-207.

Bougher NL, Grove TS, Malajczuk N, 1990 - Growth and phosphorus acquisition of karri (eucalyptus diversicolor F. muell.) seedlings inoculated with ectomycorrhizal fungi in relation to phosphorus supply. New Phytologist 114, 77-85.

Buee M, Courty PE, Mignot D, Garbaye J. 2007 - Soil niche effect on species diversity and catabolic activities in an ectomycorrhizal fungal community. Soil Biology \& Biochemistry 39, 1947-1955.

Calvaruso C, Turpault MP, Frey-Klett P. 2006 - Root-associated bacteria contribute to mineral weathering and to mineral nutrition in trees: A budgeting analysis. Applied and Environmental Microbiology 72, 1258-1266.

Cheng L, Booker FL, Tu C, Burkey KO, Zhou LS, Shew HD, Rufty TW, Hu SJ. 2012 - Arbuscular mycorrhizal fungi increase organic carbon decomposition under elevated CO2. Science 337, 1084-1087.

Clark CM, Tilman D. 2008 - Loss of plant species after chronic low-level nitrogen deposition to prairie grasslands. Nature 451, 712-715.

Clemmensen KE, Bahr A, Ovaskainen O, Dahlberg A, Ekblad A, Wallander H, Stenlid J, Finlay RD, Wardle DA, Lindahl BD. 2013 - Roots and associated fungi drive long-term carbon sequestration in boreal forest. Science 339, 1615-1618.

Clemmensen KE, Finlay RD, Dahlberg A, Stenlid J, Wardle DA. 2015 - Carbon sequestration is related to mycorrhizal fungal community shifts during long-term succession in boreal forests. New Phytologist 205, 1525-1536.

Courty PE, Buee M, Diedhiou AG, Frey-Klett P, Le Tacon F, Rineau F, Turpault MP, Uroz S, Garbaye J. 2010 - The role of ectomycorrhizal communities in forest ecosystem processes: New perspectives and emerging concepts. Soil Biology \& Biochemistry 42, 679-698.

De Souza K, Kituyi E, Harvey B, Leone M, Murali KS. 2015 - Vulnerability to climate change in three hot spots in Africa and Asia: key issues for policy-relevant adaptation and resiliencebuilding research. Regional Environmental Change 15, 747-753.

Dickie IA, Bolstridge N, Cooper JA, Peltzer DA. 2010 - Co-invasion by Pinus and its mycorrhizal fungi. New Phytologist 187, 475-484.

Drigo B, Kowalchuk GA, van Veen JA. 2008 - Climate change goes underground: effects of elevated atmospheric $\mathrm{CO} 2$ on microbial community structure and activities in the rhizosphere. Biology and Fertility of Soils 44, 667-679.

Drigo B, Pijl AS, Duyts H, Kielak A, Gamper HA, Houtekamer MJ, Boschker HTS, Bodelier PLE, Whiteley AS, van Veen JA, Kowalchuk GA. 2010 - Shifting carbon flow from roots into associated microbial communities in response to elevated atmospheric CO2. Proceedings of the National Academy of Sciences of the United States of America 107, 10938-10942. 
Ekblad A, Wallander H, Carlsson R, HussDanell K. 1995 - Fungal biomass in roots and extramatrical mycelium in relation to macronutrients and plant biomass of ectomycorrhizal Pinus sylvestris and Alnus incana. New Phytologist 131, 443-451.

Fellbaum CR, Gachomo EW, Beesetty Y, Choudhari S, Strahan GD, Pfeffer PE, Kiers ET, Bucking H. 2012 - Carbon availability triggers fungal nitrogen uptake and transport in arbuscular mycorrhizal symbiosis. Proceedings of the National Academy of Sciences of the United States of America 109, 2666-2671.

Finlay RD, Read DJ. 1986 - The structure and function of the vegetative mycelium of ectomycorrhizal plants. 2. the uptake and distribution of phosphorus by mycelial strands interconnecting host plants. New Phytologist 103, 157-165.

Finzi AC, Canham CD, Van Breeman N. 1998 - Canopy tree-soil interactions within temperate forests: Species effects on $\mathrm{pH}$ and cations. Ecological Applications 8, 905-905.

Godbold DL, Hoosbeek MR, Lukac M, Cotrufo MF, Janssens IA, Ceulemans R, Polle A, Velthorst EJ, Scarascia-Mugnozza G, De Angelis P, Miglietta F, Peressotti A. 2006 - Mycorrhizal hyphal turnover as a dominant process for carbon input into soil organic matter. Plant and Soil 281, 15-24.

Griffiths B, Robinson D. 1992 - Root-induced nitrogen mineralization - a nitrogen balance model. Plant and Soil 139, 253-263.

Helgason T, Daniell T, Husband R, Fitter A, Young J. 1998 - Ploughing up the wood-wide web? Nature 394, 431-431.

Herman DJ, Firestone MK, Nuccio E, Hodge A. 2012 - Interactions between an arbuscular mycorrhizal fungus and a soil microbial community mediating litter decomposition. Fems Microbiology Ecology 80, 236-247.

Hibbett DS, Gilbert LB, Donoghue MJ. 2000 - Evolutionary instability of ectomycorrhizal symbioses in basidiomycetes. Nature 407, 506-508.

Hobbie EA. 2006 - Carbon allocation to ectomycorrhizal fungi correlates with belowground allocation in culture studies. Ecology 87, 563-569.

Hodge A, Campbell CD, Fitter AH. 2001 - An arbuscular mycorrhizal fungus accelerates decomposition and acquires nitrogen directly from organic material. Nature 413, 297-299.

Hodge A. 2001 - Arbuscular mycorrhizal fungi influence decomposition of, but not plant nutrient capture from, glycine patches in soil. New Phytologist 151, 725-734.

Hogberg MN, Hogberg P. 2002 - Extramatrical ectomycorrhizal mycelium contributes one-third of microbial biomass and produces, together with associated roots, half the dissolved organic carbon in a forest soil. New Phytologist 154, 791-795.

Holden SR, Treseder KK. 2013 - Fires as global change: Responses by mycorrhizal fungi. Phytopathology 103, 183-183.

Hu YJ, Rillig MC, Xiang D, Hao ZP, Chen BD. 2013 - Changes of am fungal abundance along environmental gradients in the arid and semi-arid grasslands of northern China. Plos One 8.

Intergovernmental Panel on Climate Change (IPCC). 2001 - The scientific basis. (Houghton, J.T. , Ding, Y., Griggs, D.J., Noguer, M., van der Linden, P.J., Xiaosu, D., editors) Cambridge University Press, U.K.

Iversen CM, Keller JK, Garten CT, Norby RJ. 2012 - Soil carbon and nitrogen cycling and storage throughout the soil profile in a sweetgum plantation after 11 years of $\mathrm{CO} 2$-enrichment. Global change biology 18, 1684-1697.

Jin H, Pfeffer PE, Douds DD, Piotrowski E, Lammers PJ, Shachar-Hill Y. 2005 - The uptake, metabolism, transport and transfer of nitrogen in an arbuscular mycorrhizal symbiosis. New Phytologist 168, 687-696.

Johnson NC, Angelard C, Sanders IR, Kiers ET. 2013 - Predicting community and ecosystem outcomes of mycorrhizal responses to global change. Ecology Letters 16, 140-153.

Jones MD, Durall D, Tinker P. 1998 - A comparison of arbuscular and ectomycorrhizal Eucalyptus coccifera: growth response, phosphorus uptake efficiency and external hyphal production. New Phytologist 140, 125-134. 
Leake JR, Johnson D, Donnelly DP, Muckle GE, Boddy L, Read DJ. 2004 - Networks of power and influence: the role of mycorrhizal mycelium in controlling plant communities and agroecosystem functioning. Canadian Journal of Botany-Revue Canadienne De Botanique $82,1016-1045$.

Leigh J, Fitter AH, Hodge A. 2011 - Growth and symbiotic effectiveness of an arbuscular mycorrhizal fungus in organic matter in competition with soil bacteria. Fems Microbiology Ecology 76, 428-438.

Leski T, Rudawska M, Aucina A, Skridaila A, Riepsas E, Pietras M. 2009 - Influence of pine and oak litter on growth and mycorrhizal community structure of Scots pine seedlings in bareroot nursery conditions. Sylwan 153, 675-683.

Leyval C, Berthelin J. 1989 - Interactions between laccaria-laccata, agrobacterium-radiobacter and beech roots influence on $\mathrm{P}, \mathrm{K}, \mathrm{Mg}$, and Fe mobilization from minerals and plant growth. Plant and Soil 117, 103-110.

Lilleskov EA, Hobbie EA, Horton TR. 2011 - Conservation of ectomycorrhizal fungi: exploring the linkages between functional and taxonomic responses to anthropogenic $\mathrm{N}$ deposition. Fungal Ecology 4, 174-183.

Liu Y, Shi G, Mao L, Cheng G, Jiang S, Ma X, An L, Du G, Collins Johnson N, Feng H. 2012 Direct and indirect influences of $8 \mathrm{yr}$ of nitrogen and phosphorus fertilization on Glomeromycota in an alpine meadow ecosystem. New Phytologist 194, 523-535.

Lonsdale WM. 1988 - Predicting the amount of litterfall in forests of the world[J]. Ann als of Botany 61, 319-324.

Machuca A, Pereira G, Aguiar A, Milagres AMF. 2007 - Metal-chelating compounds produced by ectomycorrhizal fungi collected from pine plantations. Letters in Applied Microbiology 44, 7-12.

Magill AH, Aber JD, Currie WS, Nadelhoffer KJ, Martin ME, McDowell WH, Melillo JM, Steudler P. 2004 - Ecosystem response to 15 years of chronic nitrogen additions at the Harvard Forest LTER, Massachusetts, USA. Forest Ecology and Management 196, 7-28.

Martinez-Garcia LB, Ochoa-Hueso R, Manrique E, Pugnaire FI. 2015 - Different mycorrhizal fungal strains determine plant community response to nitrogen and water availability. Journal of Plant Nutrition and Soil Science 178, 146-154.

Mayor J, Bahram M, Henkel T, Buegger F, Pritsch K. 2015 - Ectomycorrhizal impacts on plant nitrogen nutrition: emerging isotopic patterns, latitudinal variation and hidden mechanisms. Ecology Letters 18, 96-107.

McGrath JM, Lobell DB. 2013 - Regional disparities in the CO2 fertilization effect and implications for crop yields. Environmental Research Letters 8.

Melillo JM, Houghton RA, Kicklighter DW, McGuire AD. 1996 - Tropical deforestation and the global carbon budget. Annual Review of Energy and the Environment 21, 293-310.

Meyer A, Grote R, Polle A, Butterbach-Bahl K. 2010 - Simulating mycorrhiza contribution to forest $\mathrm{C}$ and N cycling, the MYCOFON model. Plant and Soil 327, 493-517.

Mosca E, Montecchio L, Scattolin L, Garbaye J. 2007 - Enzymatic activities of three ectomycorrhizal types of Quercus robur L. in relation to tree decline and thinning. Soil Biology \& Biochemistry 39, 2897-2904.

Nazeri NK, Lambers H, Tibbett M, Ryan MH. 2014 - Moderating mycorrhizas: arbuscular mycorrhizas modify rhizosphere chemistry and maintain plant phosphorus status within narrow boundaries. Plant, Cell \& Environment 37, 911-921.

Nehls U, Bock A, Einig W, Hampp R. 2001 - Excretion of two proteases by the ectomycorrhizal fungus Amanita muscaria. Plant Cell and Environment 24, 741-747.

Ochoa-Hueso R, Perez-Corona ME, Manrique E. 2013 - Impacts of simulated n deposition on plants and mycorrhizae from spanish semiarid mediterranean shrublands. Ecosystems 16, 838-851.

Olsson PA, Thingstrup I, Jakobsen I, Baath E. 1999 - Estimation of the biomass of arbuscular mycorrhizal fungi in a linseed field. Soil Biology \& Biochemistry 31, 1879-1887. 
Paterson E, Hodge A, Thornton B, Millard P, Killham K. 1999 - Carbon partitioning and rhizosphere $\mathrm{C}$-flow in Lolium perenne as affected by $\mathrm{CO} 2$ concentration, irradiance and below-ground conditions. Global change biology 5, 669-678.

Phillips RP, Brzostek E, Midgley MG. 2013 - The mycorrhizal-associated nutrient economy: a new framework for predicting carbon nutrient couplings in temperate forests. New Phytologist $199,41-51$.

Phillips RP, Meier IC, Bernhardt ES, Grandy AS, Wickings K, Finzi AC. 2012 - Roots and fungi accelerate carbon and nitrogen cycling in forests exposed to elevated $\mathrm{CO} 2$. Ecology Letters $15,1042-1049$.

Potila H, Wallander H, Sarjala T. 2009 - Growth of ectomycorrhizal fungi in drained peatland forests with variable $\mathrm{P}$ and $\mathrm{K}$ availability. Plant and Soil 316, 139-150.

Pregitzer KS, Burton AJ, Zak DR, Talhelm AF. 2008 - Simulated chronic nitrogen deposition increases carbon storage in Northern Temperate forests. Global change biology 14, 142153.

Prescott CE. 2010 - Litter decomposition: what controls it and how can we alter it to sequester more carbon in forest soils? Biogeochemistry 101, 133-149.

Read DJ, Perez-Moreno J. 2003 - Mycorrhizas and nutrient cycling in ecosystems - a journey towards relevance? New Phytologist 157, 475-492.

Read DJ. 1991 - Mycorrhizas in ecosystems. Experientia 4, 376-391.

Rillig MC, Caldwell BA, Wosten HAB, Sollins P. 2007 - Role of proteins in soil carbon and nitrogen storage: controls on persistence. Biogeochemistry 85, 25-44.

Shi LL, Mortimer PE, Slik JWF, Zou XM, Xu JC. 2014 - Variation in forest soil fungal diversity along a latitudinal gradient. Fungal Diversity 64, 305-315.

Simard SW, Jones MD, Durall DM, Perry DA, Myrold DD, Molina R. 1997 - Reciprocal transfer of carbon isotopes between ectomycorrhizal Betula papyrifera and Pseudotsuga menziesii. New Phytologist 137, 529-542.

Smith SE, Read DJ, Harley JL. 1997 - Mycorrhizal symbiosis, 2nd ed. Academic Press, San Diego, California.

Smith SE, Read DJ. 2010 - Mycorrhizal symbiosis. Academic press, San Diego, California.

Song RQ, Ju HB, Qi JY, Zhou BR. 2007 - Effect of ectomycorrhizal fungi on seedling growth of mongol scotch pine. Journal of Fungal Research 3, 005.

Srinivasarao C, Kundu S, Shanker AK, Naik RP, Vanaja M. 2016 - Continuous cropping under elevated CO2: Differential effects on $\mathrm{C} 4$ and $\mathrm{C} 3$ crops, soil properties and carbon dynamics in semi-arid alfisols. Agriculture Ecosystems \& Environment 218, 73-86.

Sun XF, Su YY, Zhang Y, Wu MY, Zhang Z, Pei KQ, Sun LF, Wan SQ, Liang Y. 2013 - Diversity of arbuscular mycorrhizal fungal spore communities and its relations to plants under increased temperature and precipitation in a natural grassland. Chinese Science Bulletin 58, 4109-4119.

Talbot JM, Allison SD, Treseder KK. 2008 - Decomposers in disguise: mycorrhizal fungi as regulators of soil $\mathrm{C}$ dynamics in ecosystems under global change. Functional Ecology 22, 955-963.

Taylor JA. 1983 - Structure and Function of Northern Coniferous Forests-an Ecosystem Study Persson,T. Journal of Biogeography 10, 371-372.

Taylor LL, Leake JR, Quirk J, Hardy K, Banwart SA, Beerling DJ. 2009 - Biological weathering and the long-term carbon cycle: integrating mycorrhizal evolution and function into the current paradigm. Geobiology 7, 171-191.

Thomas RQ, Canham CD, Weathers KC, Goodale CL. 2010 - Increased tree carbon storage in response to nitrogen deposition in the US. Nature Geoscience 3, 13-17.

Tian CJ, Kasiborski B, Koul R, Lammers PJ, Bucking H, Shachar-Hill Y. 2010 - Regulation of the nitrogen transfer pathway in the arbuscular mycorrhizal symbiosis: gene characterization and the coordination of expression with nitrogen flux. Plant physiology 153, 1175-1187. 
Treseder KK. 2004 - A meta-analysis of mycorrhizal responses to nitrogen, phosphorus, and atmospheric CO2 in field studies. New Phytologist 164, 347-355.

Treseder KK. 2008 - Nitrogen additions and microbial biomass: A meta-analysis of ecosystem studies. Ecology letters 11, 1111-1120.

Trumbore SE, Harden JW. 1997 - Accumulation and turnover of carbon in organic and mineral soils of the BOREAS northern study area. Journal of Geophysical Research. Atmospheres 102, 28817-28830.

Turner BL. 2008 - Resource partitioning for soil phosphorus: a hypothesis. Journal of Ecology 96, 698-702.

Uroz S, Calvaruso C, Turpault MP, Pierrat JC, Mustin C, Frey-Klett P. 2007 - Effect of the mycorrhizosphere on the genotypic and metabolic diversity of the bacterial communities involved in mineral weathering in a forest soil. Applied and Environmental Microbiology 73, 3019-3027.

van der Heijden MGA, Scheublin TR. 2007 - Functional traits in mycorrhizal ecology: their use for predicting the impact of arbuscular mycorrhizal fungal communities on plant growth and ecosystem functioning. New Phytologist 174, 244-250.

Van Scholl L, Smits MM, Hoffland E. 2006 - Ectomycorrhizal weathering of the soil minerals muscovite and hornblende. New Phytologist 171, 805-814.

Verbruggen E, Roling WFM, Gamper HA, Kowalchuk GA, Verhoef HA, van der Heijden MGA. 2010 - Positive effects of organic farming on below-ground mutualists: large-scale comparison of mycorrhizal fungal communities in agricultural soils. New Phytologist 186, 968-979.

Vitousek PM, Aber JD, Howarth RW, Likens GE, Matson PA, Schindler DW, Schlesinger WH, Tilman D. 1997 - Human alteration of the global nitrogen cycle: Sources and consequences. Ecological Applications 7, 737-750.

Welc M, Ravnskov S, Kieliszewska-Rokicka B, Larsen J. 2010 - Suppression of other soil microorganisms by mycelium of arbuscular mycorrhizal fungi in root-free soil. Soil Biology \& Biochemistry 42, 1534-1540.

Whiteside MD, Digman MA, Gratton E, Treseder KK. 2012 - Organic nitrogen uptake by arbuscular mycorrhizal fungi in a boreal forest. Soil Biology \& Biochemistry 55, 7-13.

Wu LL, Jacobson AD, Hausner M. 2008 - Characterization of elemental release during microbegranite interactions at $\mathrm{T}=28$ degrees C. Geochimica Et Cosmochimica Acta 72, 62016202.

Yang W, Zheng Y, Gao C, He XH, Ding Q. 2013 - The Arbuscular Mycorrhizal Fungal Community Response to Warming and Grazing Differs between Soil and Roots on the Qinghai-Tibetan Plateau. Plos One 8.

Zeglin LH, Kluber LA, Myrold DD. 2013 - The importance of amino sugar turnover to C and N cycling in organic horizons of old-growth Douglas-fir forest soils colonized by ectomycorrhizal mats. Biogeochemistry 112, 679-693. 